\title{
THE PERINATAL MORPHOGENESIS OF SELECTED LINGUAL PAPILLAE IN THE DOMESTIC CAT OBSERVED BY SCANNING ELECTRON MICROSCOPY
}

\author{
F. TICHÝ \\ Department of Anatomy, Histology and Embryology \\ University of Veterinary and Pharmaceutical Sciences, 61242 Brno
}

Received March 16, 1992

\begin{abstract}
Tichý F.: The Perinatal Morphogenesis of Selected Lingual Papillae in the Domestic Cat Observed by Scanning Electron Microscopy. Acta vet. Brno, 62, 1993: 121 - 126.

The morphogenesis of circumvallate, fungiform and filiform papillae of the tongue was studied in feline foetuses at 48 days and in kittens a day after birth. Attention was paid to the keratinization of mucosal epithelium on the dorsum linguae and to the distribution and development of taste pores of circumvallate and fungiform papillae.

The circumvallate and fungiform papillae were differentiated earlier than the filiform papillae. The keratinization of epithelium was most marked on the rostral surfaces of filiform papilla anlages.

Taste buds were most often found at the border of the dorsal surface with the papillary wall in circumvallate papillae and in the midregion of the dorsal surface in fungiform papillae. The taste buds of circumvallate and fungiform papillae showed an identical appearance.
\end{abstract}

Tongue, papillae, epithelium, taste bud, domestic cat

The development of lingual papillae has been studied in various mammalian species (Baratz and Farbman 1975). In the domestic cat, the morphogenesis of selected lingual papillae has previously been reported in relation to the progress of taste bud differentiation (Tichý 1993). The appearance of the lingual surface is markedly affected by the degree of keratinization of superficial epithelial cells (Takagi et al. 1976; Nair and Schroeder 1961; Matravers et al. 1982). Two cell types, one producing hard, the other soft keratin, have been described in the surface epithelium (Farbman 1970) and the differences in their morphology associated with production of the respective keratin kinds have been studied (Miles 1974; Hume and Potten 1976; Hofer 1981). The process of keratinization can differ within one and the same papilla (Iida et al. 1985). This has been confirmed by scanning electron microscopic studies in individual lingual papillae (Cameron 1966; Hume and Potten 1976; Tichý 1992). The differences in epithelial cells of different parts of lingual mucosa have been reported (Singh et al. 1974, 1980; Baratz and Farbman 1975; and Boshell et al. 1980, 1982) in relation to certain protein component of these cells.

Most of the findings reported above have been made in laboratory animals or primates. The mammalian species of domestic or farm animals have been studied from this point of view much less or not at all. Therefore, this study provides some data on the development of selected lingual papillae in the domestic cat.

\section{Materials and Methods}

Samples of the tongue were collected from 3 feline foetuses at 48 days after fertilization and from 3 one-day-old kittens. Age was estimated on the basis of the crown-rump length (Evans and Sack 1973). Lingual tissue $(0.5 \times 0.5 \mathrm{~cm})$ was excised from the area of body-root junction; each sample involved equal parts on both sides of the medial line. 
All samples were immediately washed in 3 consecutive baths of physiological saline, 15 min. in each, fixed with formaldehyde $(1.33 \mathrm{~mol} / \mathrm{l})$, dehydrated in a graded alcohol series $(0.6 \mathrm{mmol} / 1$, $0.96 \mathrm{mmol} / 1$ and $1.0 \mathrm{mmol} / \mathrm{l}$ ) and placed in anhydrous acetone.

The fixed specimens were dried at the critical point and coated with gold in a Balzers SCD 040 apparatus. They were examined and photographed in a Tesla BS 300 scanning electron microscope.

\section{Results}

Feline foetus at 48 days

The surface mucosa of the caudal part of dorsum linguae bore numerous developing papillae. From these, the most conspicuous and largest structures were circumvallate papillae. They presented as oval or spherical elevations separated from the surrounding surface by a shallow and narrow encircling furrow broken at several points (Plate VII., Fig. 1). Their size varied according to location. The largest papillary anlages were found near the lateral margin of the dorsum linguae but their size was decreasing towards the medial line. The mucosa in the close vicinity of the papilla formed a circular protrusion. This usually did not appear as a compact ring but was divided into two semicircular parts by shallow grooves (Fig. 1).

The other lingual papillae were less well developed in this period. The anlages of filiform papillae were dome-shaped structures situated rostral and medial to the circumvallate papillae (Plates VII., VIII., IX., Figs. 1, 2, 3). Each was encircled by a shallow invagination, caudally appearing more pronounced (Fig. 3). In the medial region of the remaining large part of the dorsum linguae, the surface was broken into protrusions, laterally increasing in height, arranged in rows following the rostral-caudal orientation (Fig. 1). The protrusions found lateral to the circumvallate papillae presented as finger-shaped structures separated by deep narrow depressions. The apices of these primitive papillae were turned caudally.

The epithelium of the lingual mucosa over the area studied was more or less uniform but for a more even and smoother appearance of the dorsal surfaces of developing papillae due to a lower degree of desquamation, as compared with the areas amongst the papillae. The bottoms of furrows and depressions which separated the anlages of papillae showed the presence of cell detritus and clusters of small spherical light bodies uniform in size (Plates IX., X., XI., Figs 3, 4, 5).

The openings of gustatory pores were largely seen on the surfaces of developing circumvallate papillae, particularly at the border of the dorsal surface with the wall. In the midregion of the dorsal surface, the occurrence of pores was less frequent. The opening was usually found at a site of contact of two or three epithelial cells or under a desquamated, keratinized epithelial cell (Fig. 4). Occasionally, there was a cluster of several openings. On the anlages of fungiform papillae, pores were found only in the central area of the dorsal surface in numbers considerably lower than on circumvallate papillae. Their openings, however, had a similar appearance in both papillary types (Fig. 3).

One-day-old kitten

The uneveness of the dorsal surface of lingual mucosa was much more pronounced compared to the previous age category. The predominant structures were again circumvallate papillae, larger in the lateral and smaller in the medial parts of the dorsum linguae (Fig. 5). Each papilla was surrounded by an encircling 
furrow with the outside ring-like vallum interrupted with several grooves varying in depth (Fig. 5). The dorsal surface of each circumvallate papillae was broken into shallow depressions and invaginations (Plate XII., Fig. 6).

The dorsum linguae around circumvallate papillae was covered with numerous filiform papillae, varying in both shape and size, separated with grooves of different size (Fig. 5). The shape most often seen was conical. Since the rostral surfaces of these papillae declined at an angle sharper than the caudal surfaces, the papillary apices were orientated caudally. The filiform papillae observed in the close vicinity of laterally situated circumvallate papillae were tall and slim (Fig. 5) while those situated further from these circumvallate papillae were lower in height and had amongst them fungiform papillae. These presented as low, dome-shaped elevations separated from the surroundings by low-depth furrows (Plate XIII., Fig. 7). The fungiform papillae were very similar in size to the filiform ones, which made their identification rather difficult and, in some cases, dependent only on the presence of gustatory pores (Plates XIII., XIV., Figs 7,8).

The surface of epithelium covering the papillae was generally even and smooth. Slightly uneven areas were due to the presence of desquamated keratinized epithelial cells which were more marked along the circumference of the dorsal surface of circumvallate papillae and on the rostral surfaces of filiform papillae (Figs 6,7). The furrows and depressions amongst the papillae were partly filled with cell detritus and, like in the period described above, showed the clusters of small light, spherical bodies (Plates XII., XV., Figs 6, 9).

Gustatory pores on circumvallate papillae were most frequently observed at the borders of the dorsal surface with the papillary wall (Fig. 6). Occasionally, they opened to the bottoms of shallow depressions in the midregion of the dorsal surface. Near the pore openings, cell detritus or desquamated epithelial cells were frequent findings. Gustatory pores were observed singly or in groups, sometimes in the middle of an intact epithelial cell (Fig. 9). Gustatory pores on fungiform papillae were located to the middle part of the dorsal surface (Figs $7,8)$. Their shape and opening were similar to those on circumvallate papillae (Plate XVI., Fig. 10).

\section{Discussion}

The observations on the maturation process of the feline lingual mucosa made in this study by scanning electron microscopy are in agreement with the results of light microscopic studies published previously (Tichý 1993).

Circumvallate papillae were the most distinct and best differentiated structures on the feline lingual mucosa. It was of interest to find that laterally situated papillae were larger than those seen near the medial line of the dorsum linguae. Similar observation has been made in sheep (Tichý 1992) and can be explained by the fact that circumvallate papillae first arise at the lateral parts and thus their morphogenesis is best advanced there. It is also possible that this irregular differentiation can be influenced by a different way of innervation in each part of the tongue (Zalewski 1969; Oakley 1970). This factor is likely to be involved also in the commencement and development of fungiform papillae. These develop in close relation to circumvallate papillae in domestic cats, as well as in sheep and swine (Tichý 1992).

In the feline foetus, the differentiation of filiform papillae is a distinct feature from day $48 \mathrm{on}$. While on this day, these papillae appear only as inconspicuous 
elevations, which are slightly larger when situated lateral to circumvallate ones, at birth they present as slim, finger-shaped structures with their apices following the aboral orientation. Fungiform papillae are difficult to distinguish amongst them. This progressive development of filiform papillae in this period is accounted for by their unique function in liquid feed intake.

The keratinization and subsequent desquamation of flat superficial eithelial cells was observed as early as at 48 days. This process was most marked on circumvallate and fungiform papillae, which is in agreement with the findings in the pig (Tichý 1992). The intensity of desquamation in the cat was lower than in the pig, but comparable with this process in sheep. In contrast to the two previously studied species, the feline lingual mucosa was free from areas of eroded epithelial cells, which suggests a completed development of this epithelium. This has been confirmed by earlier light' microscopy observations (Tichý 1993). It is clear that, relative to the length of gestation, the differentiation of lingual mucosa epithelium is completed earlier in the domestic cat than in sheep or swine. In this study, the view held earlier (Tichy 1992) that lingual epithelium matures differently in different parts of the dorsum linguae cannot be supported.

Slight differences in the intensity of epithelial desquamation on filiform papillae were seen in the kitten, with the desquamation being more marked on the rostral than the caudal surfaces. Some differences between epithelia cells on these respective areas have been noted in the pig and dog (Boshell et al. 1980; Singh et al. 1980; Iida et al. 1985) and were studied with respect to keratin content, and to the strength and closeness of intercellular links of the epithelial cells. It can be speculated than in the domestic cat, as in the pig (Tichý 1992), higher desquamation of cells on the rostral surface of filiform papillae is associated with the need for faster replacement of cells involved in food intake.

Gustatory pores on the dorsal surfaces of circumvallate papillae were found in low numbers in the feline foetus at 48 days and only occasionally in the one-day-old kitten. In both instances, the pores were accumulated at the boundary of the wall with the dorsal surface. The presence of gustatory pores in the midregion of the dorsal surfaces of fungiform papillae was in agreement with the findings made by light microscopy (Tichy 1993). The appearance of the two papillary types in the domestic cat is identical, as already observed in sheep and swine (Tichý 1992). There were no differences due to the presence or absence of microvilli in taste bud cells within the pores of the circumvallate and fungiform papillae observed by some authors in the electron microscope (Murray and Murray 1970).

The gustatory pore usually opens at a site where several cells make contact or under a desquamated epithelial cell. On the tongue of the kitten, the pore was frequently observed in the middle of an intact flat epithelial cell. This is in agreement with the previous findings in sheep and swine (Tichý 1992). The different pore openings are likely to be associated with the process of continuous exchange of the superficial epithelial cells but may also be related to the "age" of the pore, i.e., a pore developed earlier is situated in the centre of an intact epithelial cell. The latter opening was more often found in the kitten, i.e., in the higher age category. The observations by light microscopy suggest (Tich ý 1993) that gustatory pores are formed gradually, not at the same time in all the taste buds.

The small light spherical bodies found in depressions and invaginations amongst lingual papillae in this study, as well as previously in sheep and swine (Tichý 
1992), are considered to be lymphocytes either originating from amnionic fluid or associated with the differentiation of the tonsilla lingualis.

\section{Perinatální morfogeneze některých papil jazyka kočky $v$ rastrovacím elektronovém mikroskopu}

Postup morfogeneze hrazených, houbovitých a mechanických papil byl sledován na vzorcích jazyka fetů kočky stáŕi 48 dnů a jazyka kotat stárí 1 den po narození. $V$ této souvislosti byla pozornost zaměřena rovněž na vzhled a intenzitu keratinizace epitelu sliznice dorsum linguae a na lokalizaci a utváření chutových pórů na papilách hrazených a houbovitých.

Papily hrazené a houbovité se tvarově diferencují dřive než papily ostatních typů. Keratinizace epitelu je nejvýraznějši na rostrálních plochách základů papil mechanických.

Chutové póry jsou lokalizovány ponejvíce na rozhraní dorsální plochy a stěny papily hrazené a ve strední části dorsální plochy papily houbovité. Vzhled chutových pórů na hrazené i houbovité papile je shodný.

\section{Перинатальный морфогенез некоторых сосочков языка кошки В растровом электронном микроскопе}

Нами проводились исследования морфогенеза желобоватых, грибовидных и механических сосочков на образцах языка плодов кошки в возрасте 48 сүток и языка котят в возрасте 1 сутки после рождения. Внимание направили также на внешний вид и интенсивность кератинизации энителия слизистой спинки языка, на определение места и формирование вкусовых отверстий на желобоватых и грибовидных сосочках.

Дифференциация формы желобоватых и грибовидных сосочкоз протекает раньше сосочков остальных типов. Кератинизация эпителия самая выразительная на истонченных поверхностях основания механических сосочков.

Вкусовые отверстия большей частю расположены на рубеже дорсальной поверхности и стенки желобоватого сосочка, а также в центральной части дорсальной поверхности грибовидного сосочка. Внешний вид вкусовых отверстий на желобоватом и грибовидном сосочках одинаковый.

\section{References}

BARATZ, R. S. - FARBMAN, A. I.: Morphogenesis of rat lingual filiform papillae. Am. J. Anat., 143, 1975: 283-302

BOSHELL, J. L. - SINGH, B. B. - BREWER, P. D.: Histological and ultrastructural observations of eosinophilic keratohyalin granules in filiform papillae of pig tongue. Acta anat., 108, 1980: $295-300$

BOSHELL, J. L. - WILBORN, W. H. - SINGH, B. B.: Filiform papillae of cat tongue. Acta anat., 114, 1982: 97-105

CAMERON, I. L.: Cell proliferation, migration and specialization in the epithelium of the mouse tongue. J. exp. Zool., 163, 1966: 271-284 
EVANS, H. E. - SACK, W. O.: Prenatal development of domestic laboratory mammals. Growth curves, external features and selected references. Anat., Histol., Embryol., 2, 1973: 11-45. (Zbl. Vet. Med. C2)

FARBMAN, A. I.: The dual pattern of keratinization in filiform papillae on rat tongue. J. Anat., 106, 1970: $233-242$

HOFER, H. O.: Microscopic anatomy of the apical part of the tongue of Lemur fulvus (primates). Gegenbaurs morph. Jb., 127, 1981: 343-363

HUME, W. J. - POTTEN, C. S.: The ordered columnar structure of mouse filiform papillae. J. Cell Sci., 22, 1976: 149-160

IIDA, M. - YOSHIOKA, I. - MUTO, H.: Three-dimensional and surface structures of rat filiform papillae. Acta anat., 121, 1985: 237-244

MATRAVERS, J. M. - HEANEY, T. G.-APPLETON, J.: Computer analysis of the surface ultrastructural features of porcine oral mucosa. Archs. oral Biol., 27, 1982: 481-485

MILES, A. E. E.: The behaviour of the dorsal mucosa of the rat tongue in organ culture. J. Anat., 117, 1974: $541-552$

MURRAY, R. G. - MURRAY, A.: The anatomy and ultrastructure of taste endings. In: (ed. by) G. E. W. Wolstenholme and J. Knight: Taste and smell in vertebrates. London, J. and A. Churchill, 1970: 3-30

NAIR, P. N. R. - SCHROEDER, H. E.: Variation and density of microplications in superficial cells of the normal oral lining mucosa in the monkey, Macacus fascicularis. Archs. oral Biol., 26, 1981: $837-843$

OAKLEY, B.: Reformation of taste buds by crossed sensory nerves in the rat's tongue. Acta physiol. scand., 79, 1970: 88-94

SINGH, B. B.-BAKER, R.-BOSHELL, J.-McKINNEY, R. V.: Observations on the eosinophilic granules in the dorsal papillae of the dog tongue. J. oral Path., 9, 99-105

SINGH, B. B. - McKINNEY, R. V.-ALLEN, E. - BAKER, R. - KOLAS, S.: Observations on keratohyaline and eosinophilic bodies of tongue epithelia from hamster, rat, mouse, quinea pig and dog. Anat. Rec., 178, 1974: 464

TAKAGI, T.-SAITO, H.-ASO, N.: Mechanism on the differentiation of microridges. Scanning electron microscopy of the surface structures of epithelial cells of the developing human tongue (in Japanese). Jap. J. oral Biol., 18, 1976: 418-434

TICHÝ, F.: The Morphogenesis of Selected Lingual Papillae in Ovine and Porcine Foetuses Observed by Scanning Electron Microscopy. Acta vet. Brno, 61, 1992: 3-10

TICHYY, F.: The Morphogenesis of Circumvallate Papillae and the Differentiation of Taste Buds in the Domestic Cat in Ontogeny Acta vet. Brno, 62, 1993: 19-26

ZALEWSKI, A. A.: Role of nerve and epithelium in the regulation of alkaline phosphatase activity in gustatory papillae. Exp. Neurol., 23, 1969: 18-28 
Tichý, F.: The Perinatal Morphogenesis... pp. 121-126 Plate VII.

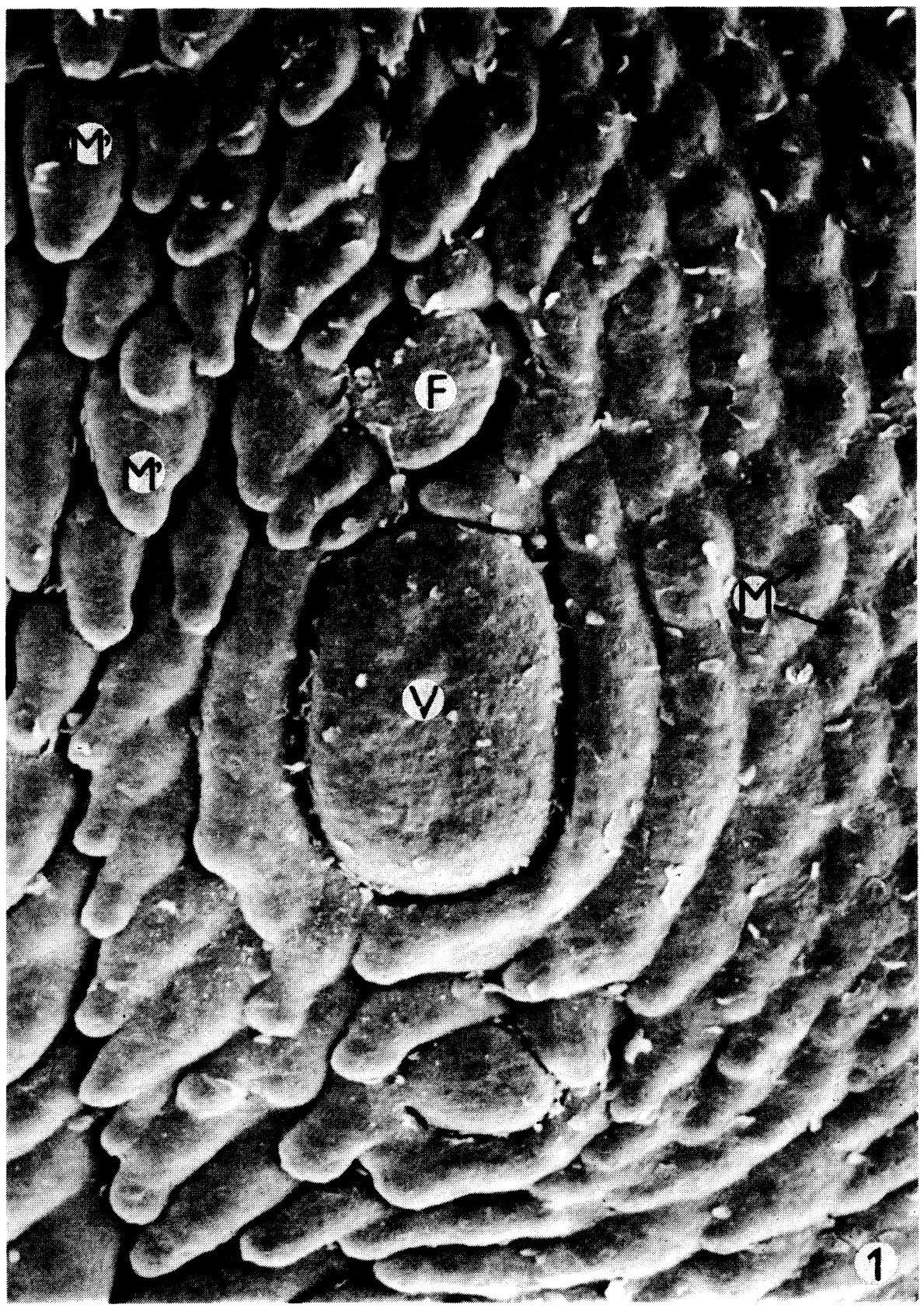

Fig. 1: Part of lingual mucosa in feline foetus at 48 days. Circumvallate papilla (V) surrounded with a distinct vallum. Fungiform papilla (F). Anlages of filiform papillae (M), not differentiated in shape; they are more pronounced (M') in areas lateral and caudal to circumvallate papillae. $\times 60$. 
Plate VIII.

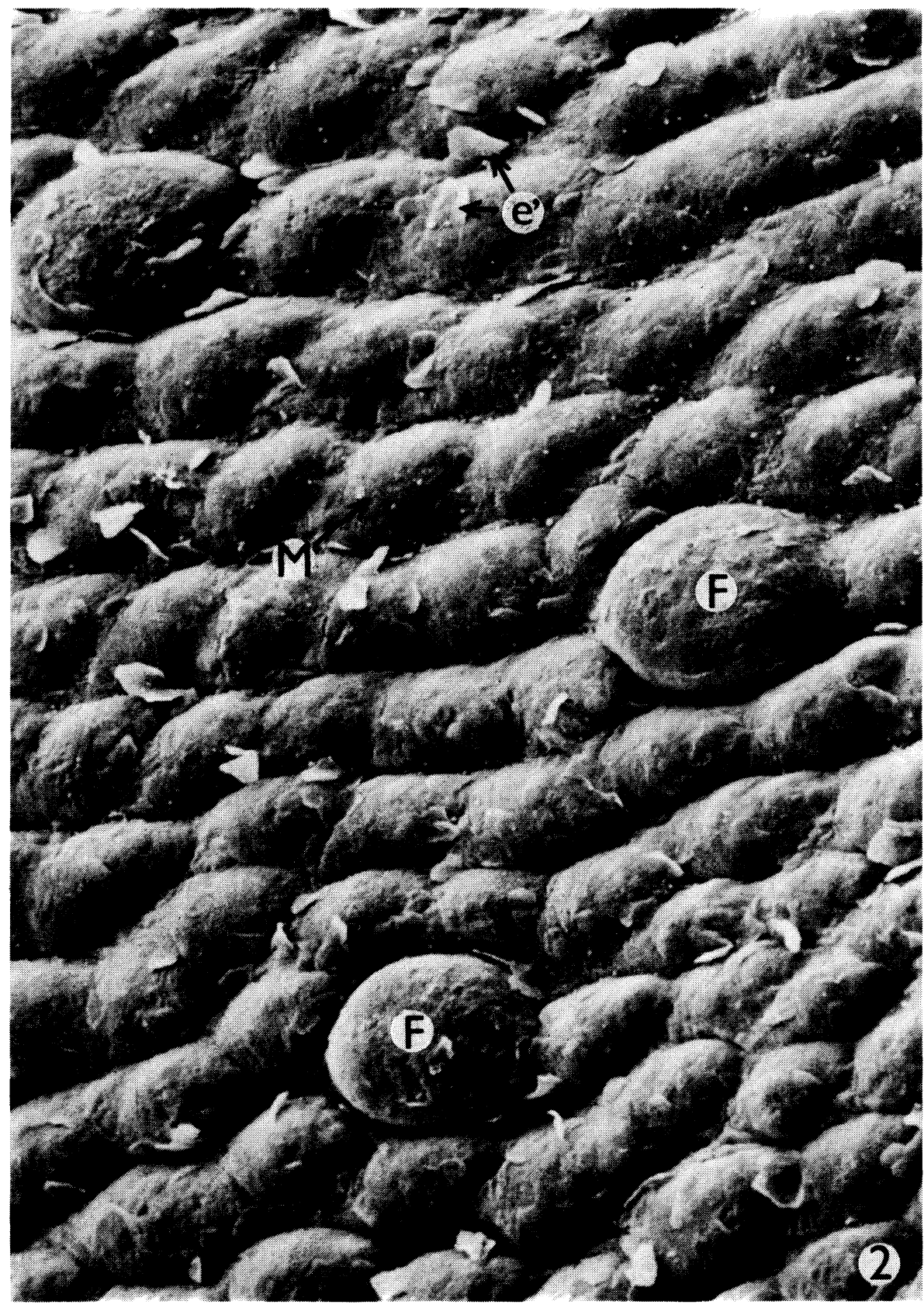

Fig. 2: Group of fungiform papillae (F) on the dorsum linguae in the 48-day-old feline foetus. Papillae of different shapes (M), desquamating keratinized cells (e'). $\times 120$. 
Plate IX

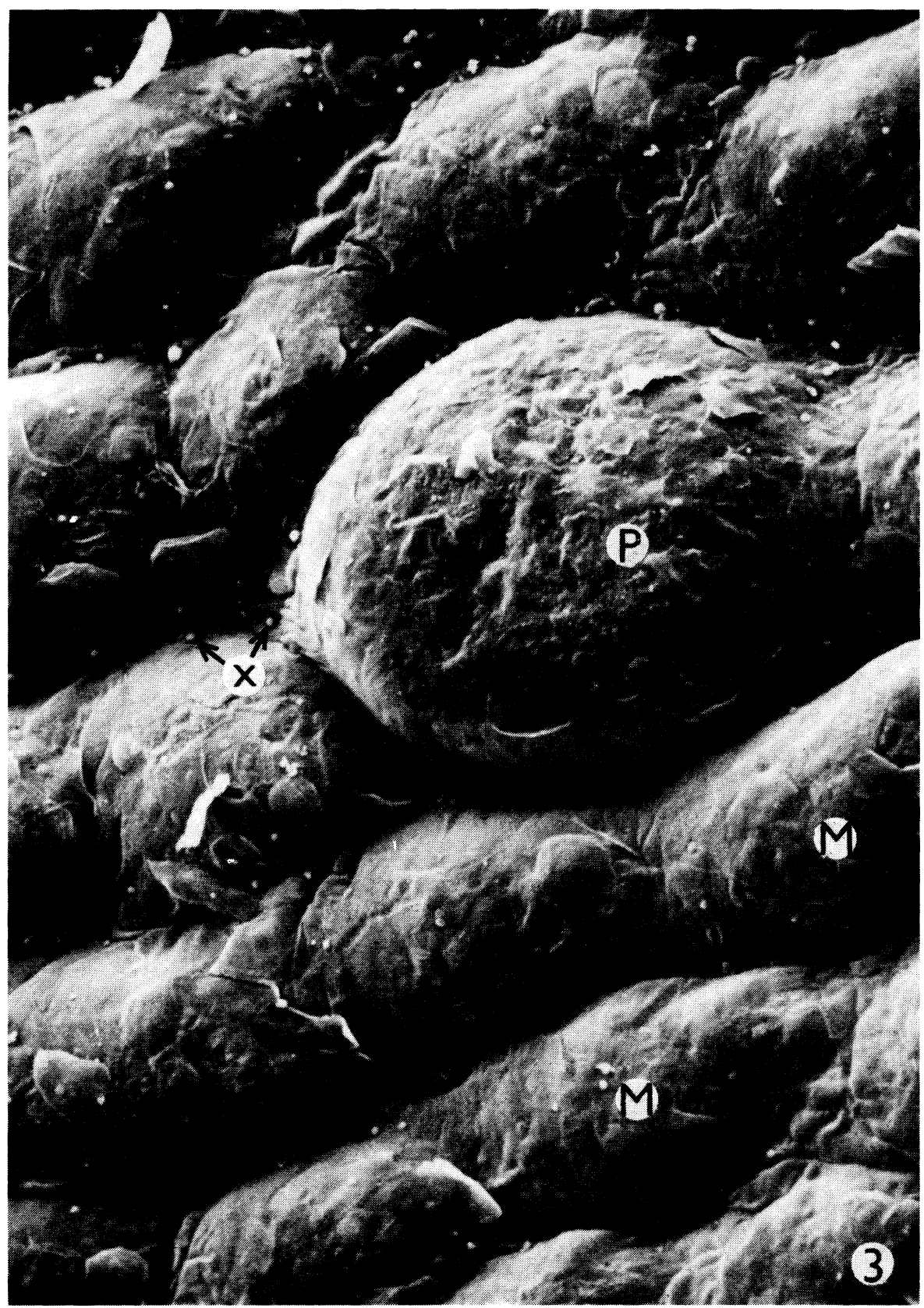

Fig. 3: Detail of Fig. 2. Gustatory pore (P) on the dorsal surface of a fungioform papilla. Papillae not differentiated in shape (M). Spherical structures on the epithelial surface $(\mathrm{x}) . \times 300$. 


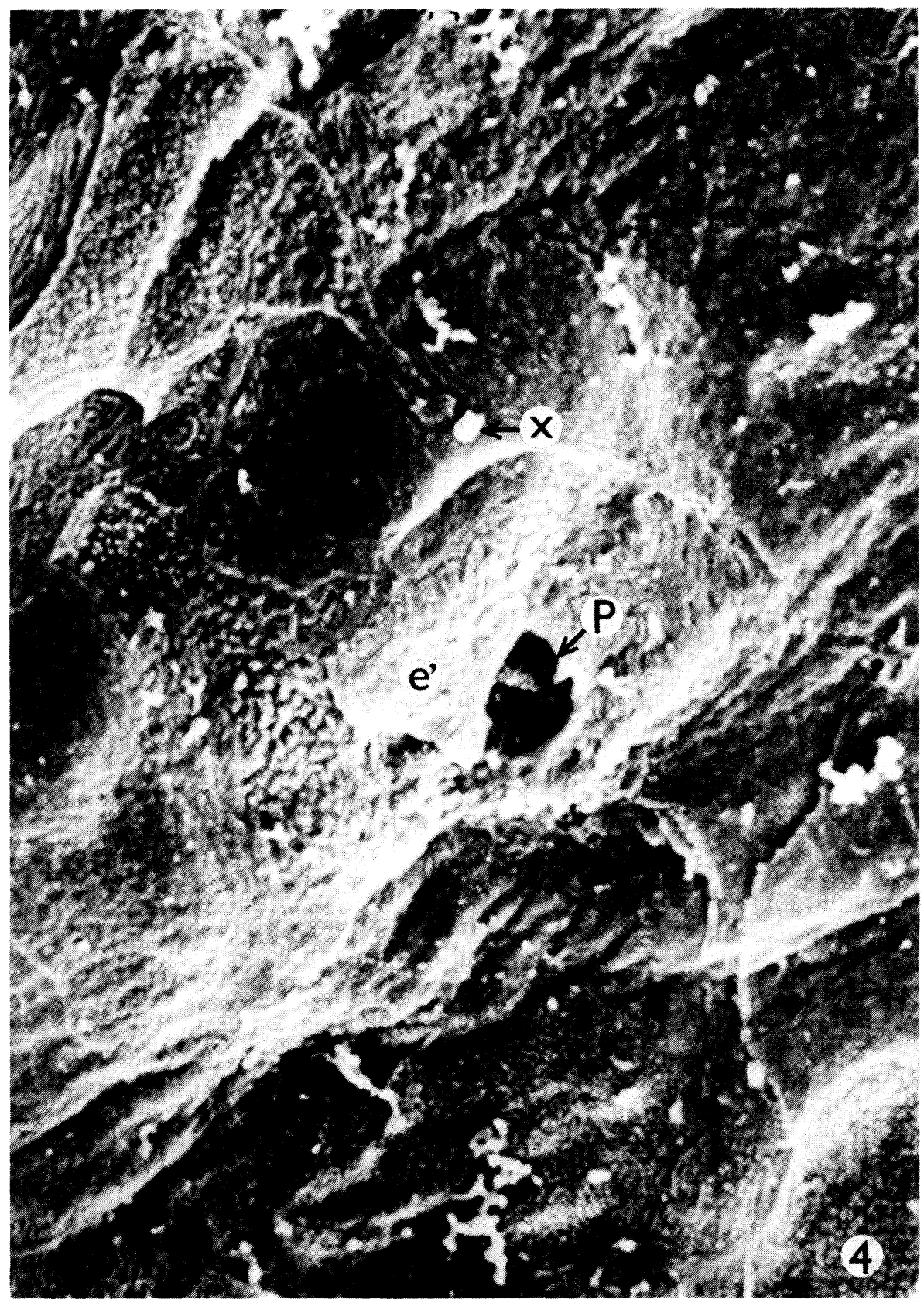

Fig. 4: Opening of a gustatory pore $(\mathrm{P})$ on the dorsal surface of a circumvallate papilla in the feline foetus at 48 days. Desquamating keratinized epithelial cell (e') and a light spherical body (x). $\times 3900$. 
Plate XI.

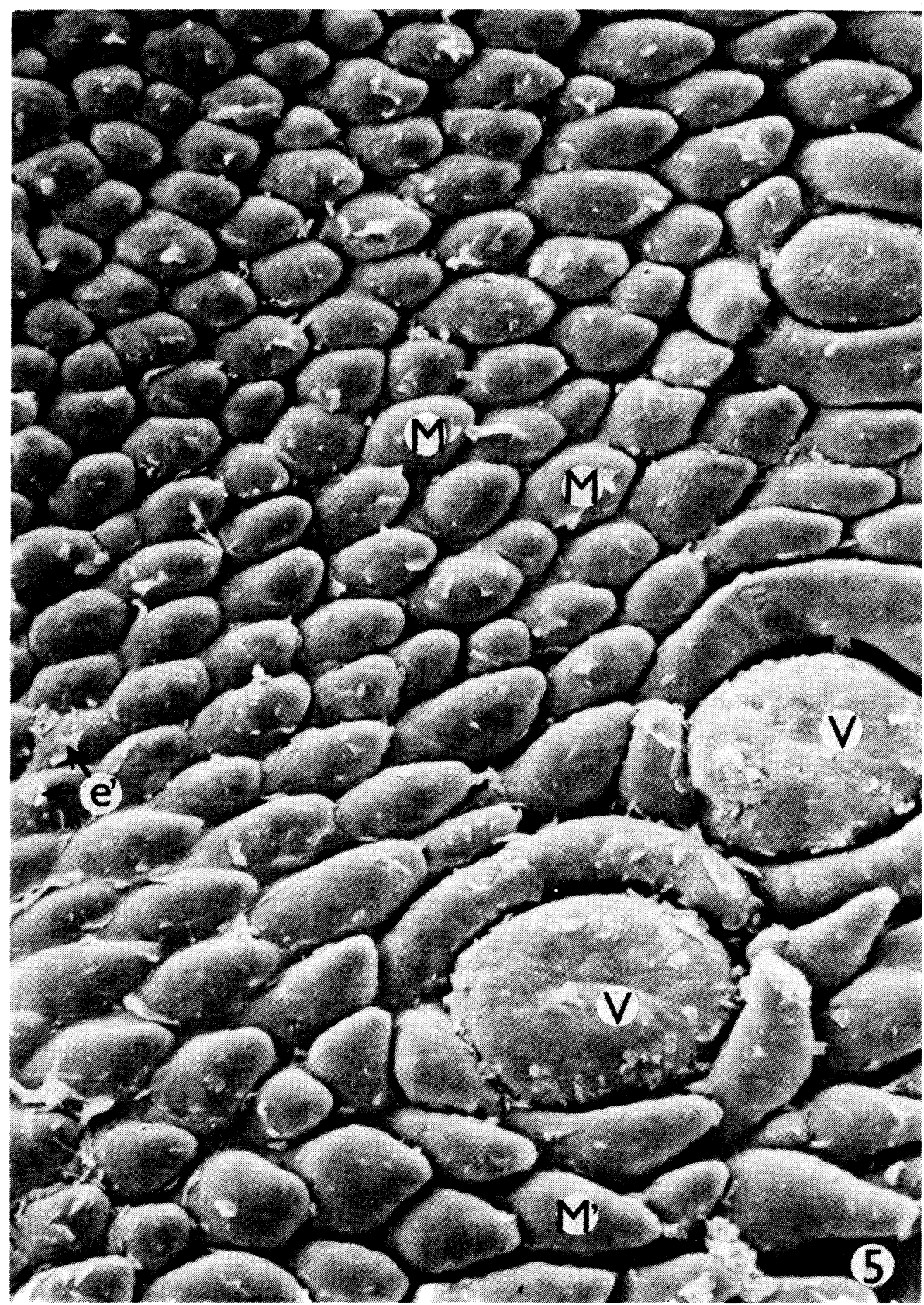

Fig. 5: Part of lingual mucosa in the one-day-old kitten. A pair of circumvallate papillae (V), filiform papillae (M). Lateral to the circumvallate papillae, the filiform papillae are larger (M'). Desquamating apithelial cells (e') on the rostral surface of filiform papillae. $\times 45$. 
Plate XII.

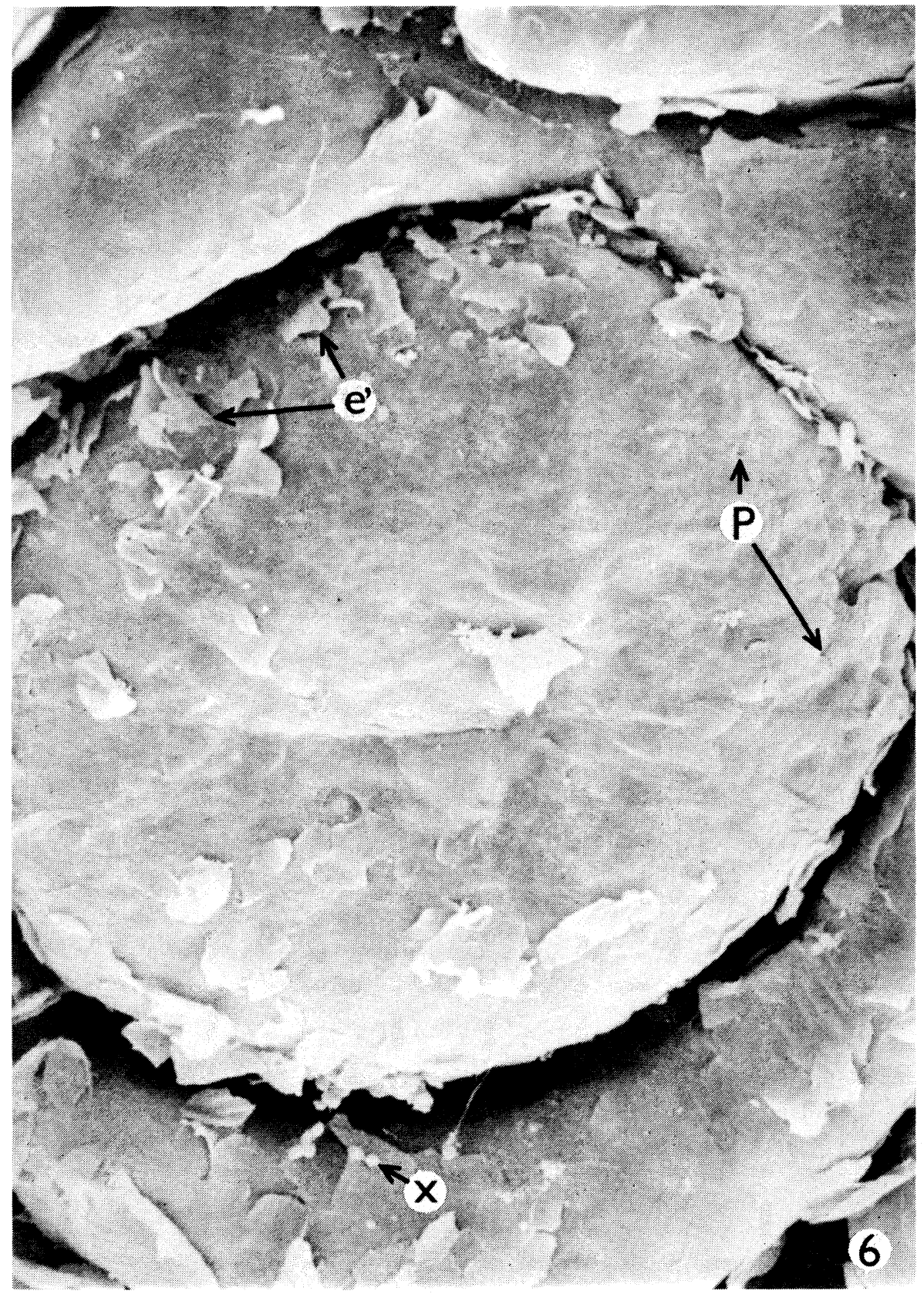

Fig. 6: Detail of Fig. 5. Gustatory pores (P) at the border of the dorsal surface with the papillary wall. At the dorsal margin are desquamating keratinized epithelial cells (e'). Spherical bodies $(\mathrm{x}) . \times 246$. 
Plate XIII.

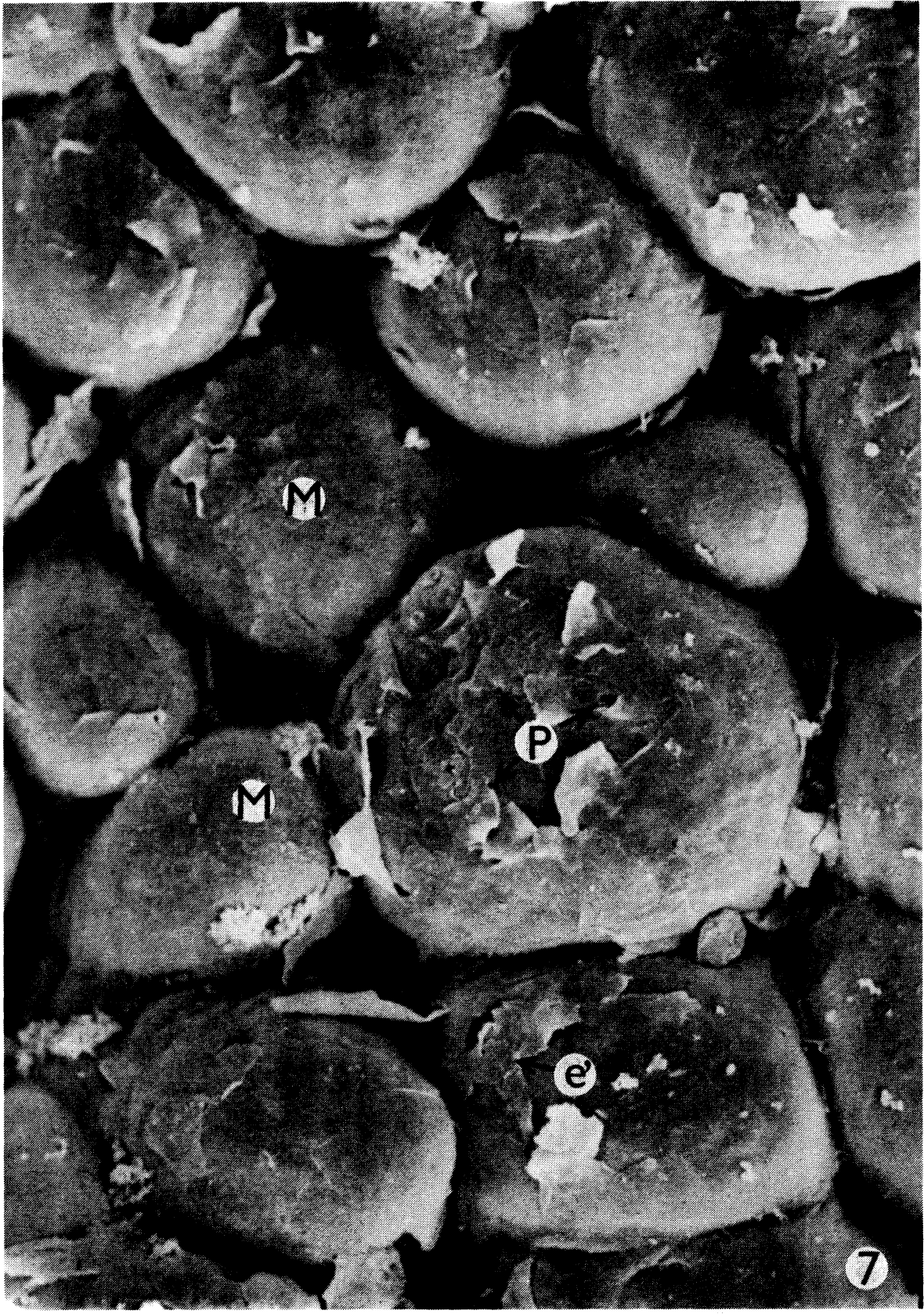

Fig. 7: Fungiform papilla with numerous gustatory pores $(\mathrm{P})$ on the dorsal surface of the tongue in the one-day-old kitten. Filiform papillae (M), marked desquamation of keratinized cells on their rostral surface (e'). $\times 307$. 


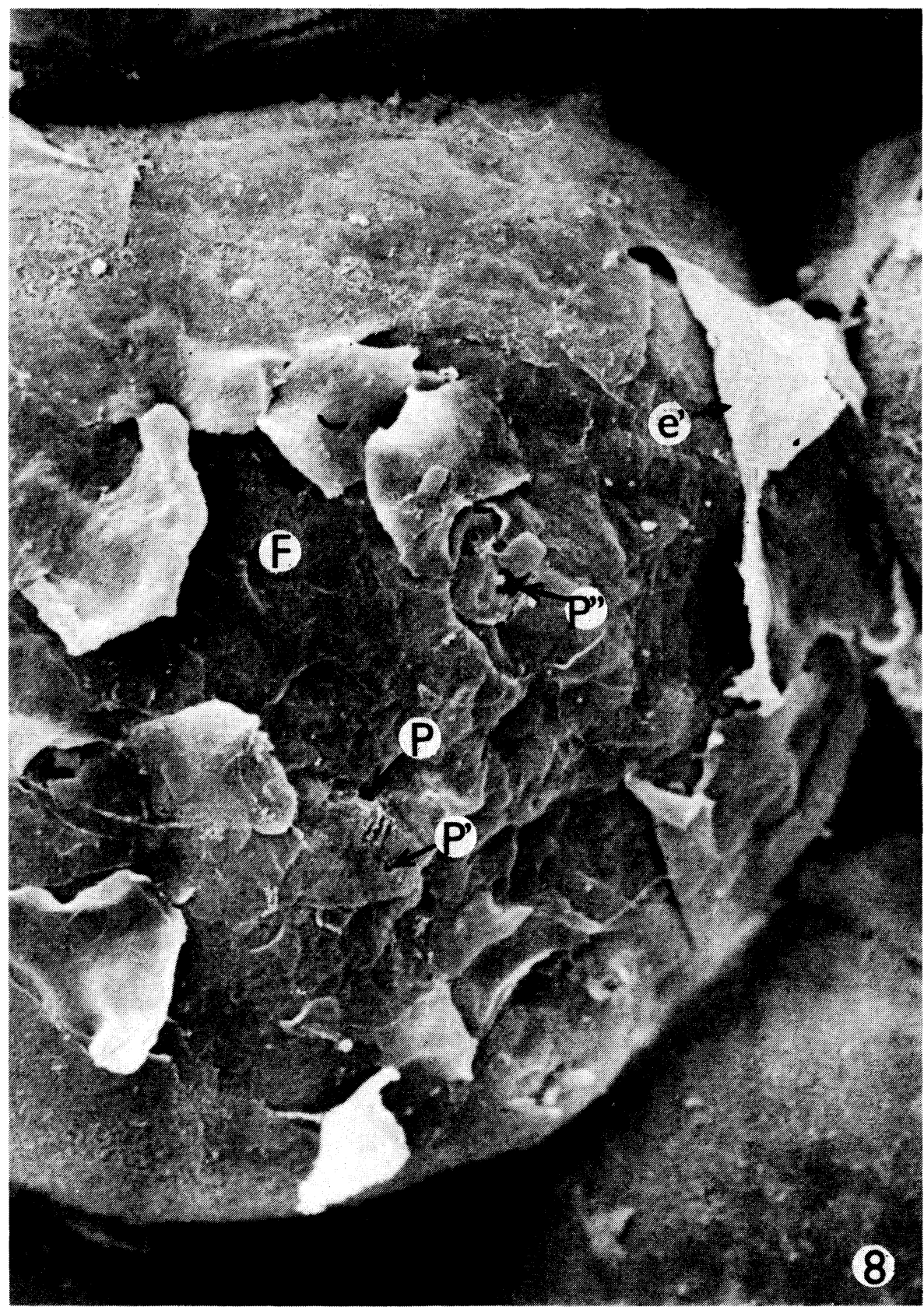

Fig. 8: Detail of the fungiform papilla (F) in Fig. 7. Gustatory pores open amongst epithelial cells (P), in at intact epithelial cells (P') and under a desquamated cell (P'). Desquamating keratinized epithelial cell (e'). $\times 847$. 
2. 2.1.2.

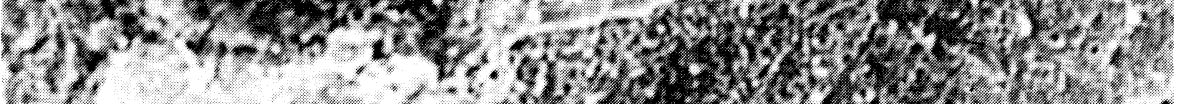
2.

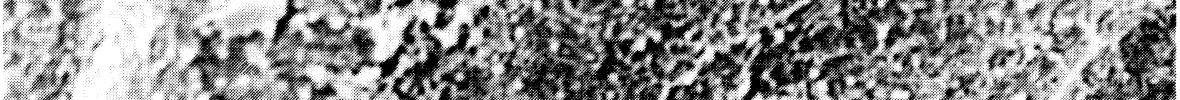

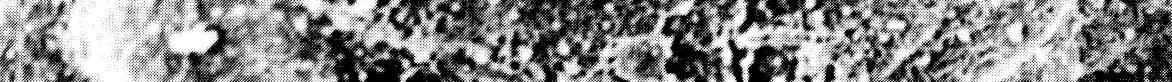
32

I.9.

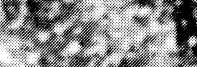

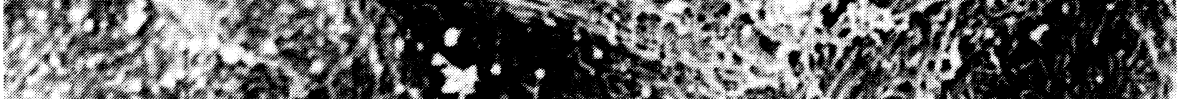

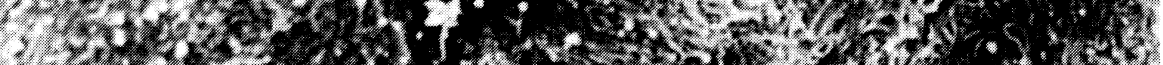

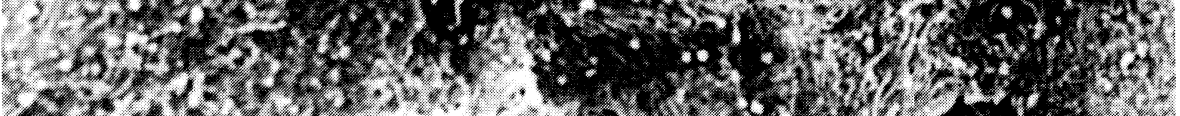

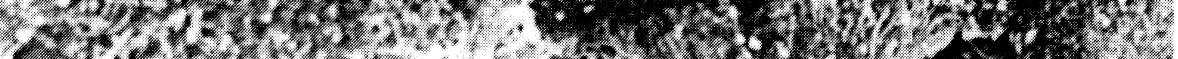

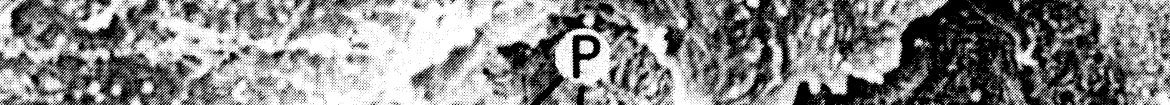

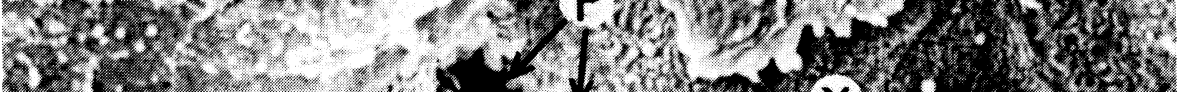

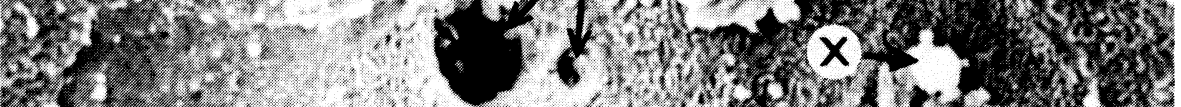

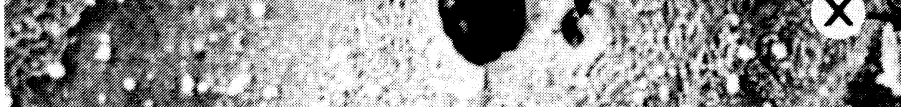

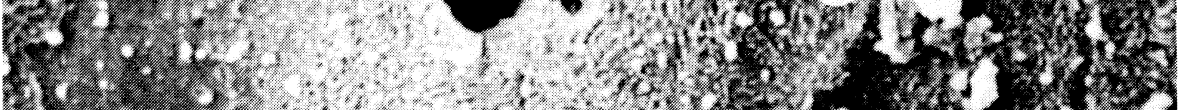

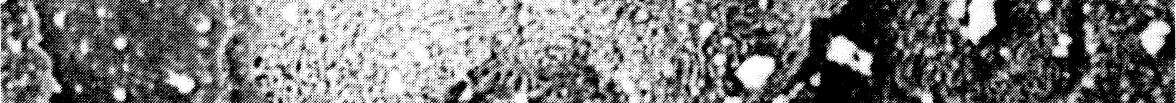

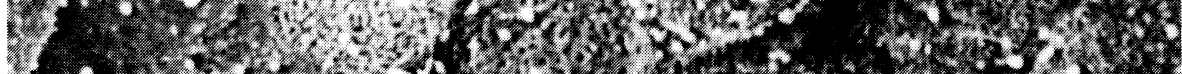

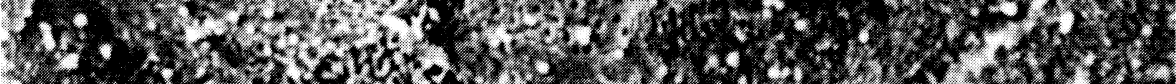

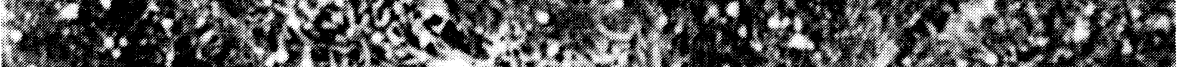

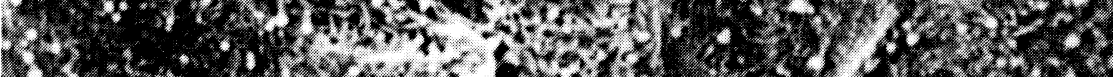

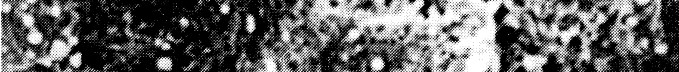

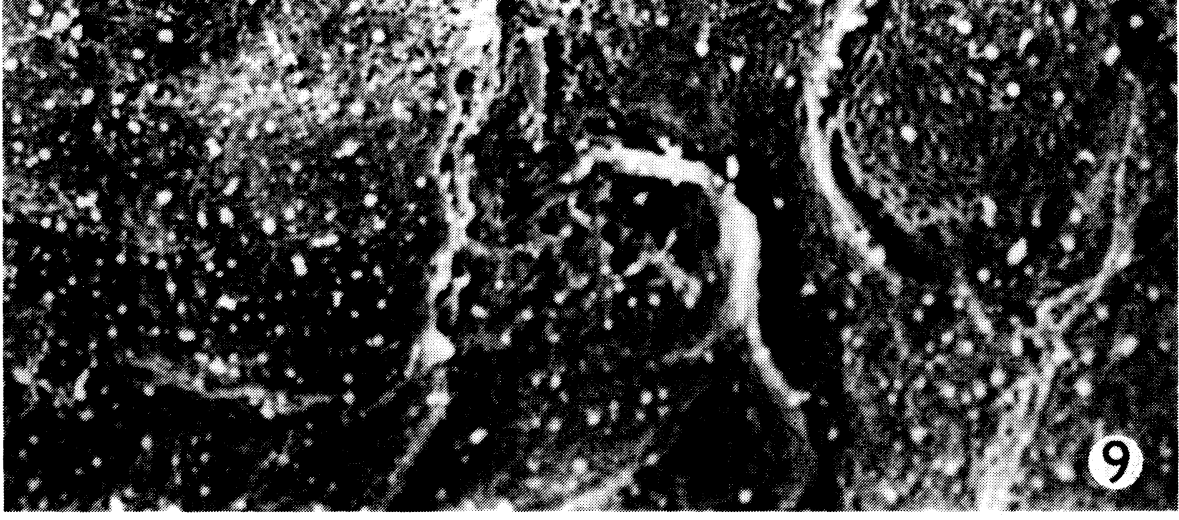

Fig. 9: Pair of gustatory pores $(\mathrm{P})$ at the margin of the dorsal surface of a circumvallate papilla in the one-day-old kitten Spherical body on the epithelial surface $(\mathrm{x}) . \times 3075$. 


\section{Plate XVI.}

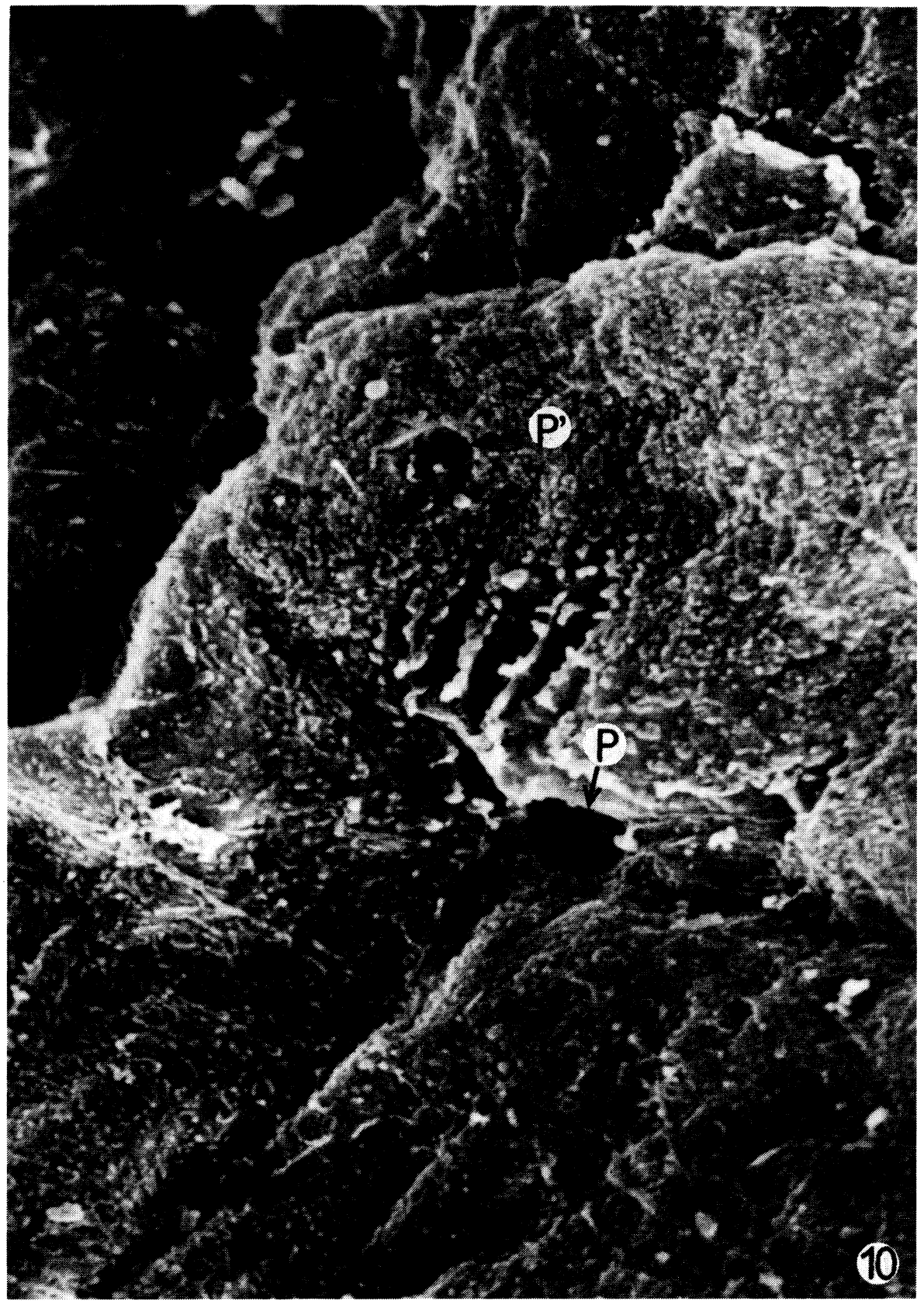

Fig. 10: Detail of the dorsal surface of the fungiform papilla in Fig. 9. A gustatory pore opening to the site of contact of three epitelilal cells $(\mathrm{P})$ and a pore opening to an intact epithelial cell (P'). $\times 4200$. 